\title{
EFFECT OF SKIP-A-DAY FEEDING REGIMES ON PRODUCTIVE PERFORMANCE AND SOME BLOOD CONSTITUENTS OF JAPANESE QUAIL
}

\author{
Abdel-Azeem F. Abdel-Azeem \\ Faculty of Agriculture, Al-Azhar University, Naser City, Cairo, Egypt

\section{SUMMARY}

This study was conducted to investigate the effect of skip-a-day (SKD) feeding regimes on productive performance, carcass characteristics, tibia bone measurements, carcass and liver composition, some blood constituents and economical efficiency of Japanese quail. Quail were subjected to one of the following regimes: the first group (control) were provided feed every day ad libitum to 43 day of age (CAL), the second group were provided feed ad libitum except for 24-hrs removal periods at 12 and 18 days of age $\left(S K D_{2}\right)$, the third group were provided feed ad libitum except for 24-hrs removal periods at 12, 18, 24 and 30 days of age $\left(S K D_{4}\right)$ and the fourth group were provided feed ad libitum except for 24-hrs removal periods at 12, 18, 24, 30, 36 and 42 days of age $\left(S K D_{6}\right)$. The obtained results indicated that $S K D$ feeding regimes did not affect negatively $(p \leq 0.05)$ on live body weight and gain at 43 day of age. While, application of SKD feeding regimes caused a significant $(p \leq 0.05)$ reduction in feed intake and total mortality rate compared with the CAL group. However, feed conversion ratio was significantly $(p \leq 0.05)$ improved due to feeding treatments. Furthermore, carcass characteristics had been affected by treatment groups, except for dressing percentage. Total edible parts were slightly higher for quail subjected to different SKD feeding regimes, while abdominal fat percentage decreased in comparison with the CAL group. The incidence of tibial dyschondroplasia phenomenon decreased by the progressive of SKD feeding regimes. Serum lipids fractions and hematological traits were gradually $(p \leq 0.05)$ increased with increasing length of SKD feeding regimes. There was evidence of an increased stress response due to feeding strategy as judged by the increase of hetrophils to lymphcytes $(H / L)$ ratio and corticosterone levels. It was shown that SKD feeding regimes during the growing period may offer an economical advantage over ad libitum feeding regimes. Based on the former results it was concluded that SKD feeding regimes was an effective method for reducing feed cost without any adverse effect on performance. Finally it can be recommended that Japanese quail producers may practice 6 day of fasting during the growing period without negative effect on performance.

\section{Keywords: Skip-a-day, productive performance, blood constituents, Japanese quail}

\section{INTRODUCTION}

It's well known that Japanese quail is a suitable model to study the metabolic response of birds naturally non-adapted to fasting. These small size birds which are easy to handle in laboratory have shorter metabolic phases of fasting and their pattern of response to starvation is similar to that observed in larger birds (Sartori et al., 1995). However, Japanese quail have the advantage of rapid growth rate, small size, good reproductive potential, short life cycle, low feed requirements, good meat taste, better laying ability and shorter time of hatching as compared with the different species of poultry (Mady, 1976 and 1981).

Feeding strategy should be used to produce birds with maximum lean body mass, best feed conversion ratio and maximum body weight. The early-life fast growth rate is accompanied by a number of problems, namely increased body fat deposition, high incidence of metabolic disorders, high mortality, and high incidence of skeletal diseases. In order to avoid these problems, early nutrient restriction programs were used (Lippens et al., 2000 and Mazzuco et al., 2000). Furthermore, limiting feed intake depresses growth during the period of restriction, but reduced growth can be later compensated (Govaerts et al., 2000). Compensatory growth is defined as a recovery from a growth deficit resulting from a limited nutrient intake (Hassanabadi and Nassiri, 2006). Also, because the development of alternative fuels including bio ethanol produced from maize and bio diesel from plant oil is likely to result in an increased cost of feed stuffs for broiler nutrition since there is an expectation that world cereal availability for livestock, especially poultry, will be highly restricted. Therefore, there is a critical need to increase efforts of reducing feed cost without compromising the final productivity.

One possible nutritional strategy of reducing feed cost is to restrict feed intake of the birds in the early stage of life (Novel et al., 2009). Skipa- day (SKD) feeding program is one of the most commonly used methods of feed restriction 
during the growing period. Although there has been a significant amount of research conducted on the effect of SKD feeding program on broilers, there is virtually little research on Japanese quail. Skip-a- day (SKD) feed removal has been reported to decrease early growth and reduce the incidence of ascites without affecting the final body weight. Lee and Lesson (2001) reported that qualitative and quantitative feed restriction programs have been successful in reducing rapid early growth and decreasing the incidence of metabolic mortality and improving nutrient utilization with compensatory growth.

The study of Julian and John (2009) indicated that plasma concentration of corticosterone and glucocorticoid hormone increased during fasting in some species of birds. Corticosterone can stimulate feed intake in quail following period of feed deprivation. Therefore, the metabolism of birds may be altered during the period of diet removal. There are few reports on the use of qualitative feed restriction of Japanese quail have been similar to those obtained with broiler chickens. However, information on the effect of SKD feeding regimes on Japanese quail is relatively few. This study was aimed to evaluate the response of Japanese quail to either $a d$ libitum feeding or SKD feed removal on the following: 1) productive performance, 2) carcass characteristics, 3) tibia bone measurements, 4) carcass and liver composition, 5) some blood constituents and 6) economical efficiency.

\section{MATERIALS AND METHODS}

\section{Site and the aim of study:}

This study was conducted at the Experimental Poultry Research Station at the Faculty of Agriculture, Al-Azhar University, Naser city, Cairo, Egypt between December 2010 and January 2011. The main objective of this study was to investigate the effect of SKD feeding regimes on productive performance, carcass characteristics, tibia bone measurements, carcass and liver composition, some blood constituents and economical efficiency of Japanese quail.

\section{Birds, management and experimental design:}

Chicks were brooded together during the first 7 day of age in electrically heated battery with raised wire floor to avoid mortality during the early age. Temperature was maintained at $35^{\circ} \mathrm{C}$ during the first week and it was gradually reduced according to usual brooding practices. Continuous lighting program was used 23L: 1 D. A total number of 420 chicks at 7 day of age were allocated in a completely randomized design into four treatment groups $(\mathrm{N}=105)$ with three replicates $(n=35)$ each as follows: the first treatment (control group), birds were provided feed ad libitum to 43 day of age (CAL); the second treatment was provided feed ad libitum except for 24-hrs removal periods at 12 and 18 days of age $\left(\mathrm{SKD}_{2}\right)$, the third treatment was provided feed ad libitum except for 24-hrs removal periods at 12,18, 24 and 30 days of age $\left(\mathrm{SKD}_{4}\right)$ and the fourth treatment birds were provided feed ad libitum except for 24-hrs removal periods at 12, 18, 24, 30, 36 and 42 days of age $\left(\mathrm{SKD}_{6}\right)$. The experiment was terminated, when the birds were at 43 day of age.

\section{Diet formulation, water and feeding practice:}

One growing diet was formulated to meet the nutrient requirements of growing Japanese quail according the NRC (1994). Diet was fortified with adequate vitamins and trace minerals. The composition of the diet is shown in Table (1). Water was offered ad libitum along the experiment. Feed deprivation began at 12 day of age by removing feeders from cages at early morning and putting in the following day. The chicks that were in the control group were fed ad libitum, while birds in treatments 2, 3 and 4 were deprived of feed for 2, 4 and 6 days, respectively during the experimental period.

\section{Data collection \\ Growth performance:}

During the experimental period, live body weights (LBW) were obtained at 7, 25 and 43 days of age. Also body weight gains (BWG) and feed intake (FI) were recorded. Feed conversion ratio (FCR) was calculated in terms of total feed (g) per (g) body weight gain. Mortality was removed and recorded on a daily basis through the experimental period to adjust FCR. Mortalities that occurred during the experiment were gross necropsied and identified as metabolic (sudden death syndrome, ascites and skeletal disorder) or nonmetabolic (other reasons).

\section{Carcass characteristics:}

At the end of growing period (43 day of age), ten quail (5 females and 5 males) from each treatment were chosen representing the average of the treatments. Birds were sacrificed and left to bleed for 3 minutes and then scalded at $60^{\circ} \mathrm{C}$ for $60 \mathrm{~s}$, after that they were feathered and manually eviscerated. Each carcass (including total edible and inedible parts) was weighed to record the dressed carcass weights. All values were calculated as percentages of live body weights. Abdominal fat pad (including fat adhering to the gizzard and proventriculus were removed and weighed). Also, the length of small intestine and cecum were measured.

\section{Carcass composition:}

In order to determine the effect of SKD feeding regimes on carcass composition, five carcasses were taken from each treatment after measuring carcass characteristics. Carcasses were 
frozen at $-20^{\circ} \mathrm{C}$ until analysis. For determining dry matter (DM) and moisture (MO) contents, carcasses were dried in an oven at $100^{\circ} \mathrm{C}$ for 6 hrs. The whole dried carcasses were then homogenized after drying using a Waring 4L blender. Sample were taken and finely ground to analysis. Dry matter was determined as percentages of total wet carcass weight. Total carcasses protein (Nx6.25), ash and ether extract (EE) were analyzed according to AOAC (1994). Ether extract was determined by extraction using the Soxelt apparatus. The percentages of carcass crude protein $(\mathrm{CP})$, ash and $\mathrm{EE}$ were reported on a DM basis.

\section{Liver composition:}

After sacrificing the birds, livers were taken and frozen at $-20^{\circ} \mathrm{C}$ for determination of liver composition. Livers were dried in a Muffle furnce at $60{ }^{\circ} \mathrm{C}$ for $6 \mathrm{hr}$. Dry liver weight was obtained by multiplying the DM percentages by the wet liver weight. Liver $\mathrm{CP}(\mathrm{N} \times$ 6.25), EE and ash percentages were determined on a DM basis according to AOAC (1994).

\section{Tibia bone measurements:}

After measuring carcass characteristics, both left and right legs were removed from the carcass to examine the tibia bone measurements including: tibia weight $(\mathrm{g})$, length $(\mathrm{cm})$, width (cm), ash, calcium (Ca \%), phosphorous $(\mathrm{Ph} \%)$ and tibial dyschondroplasia (TD). The head of the tibio-tarsus was cut with a sharp knife on both sides. The assessment of TD was made by using a scale from 0 to 3 as described by Edwards (1984) as follows:

0 - The bone structure of the dissected bone surface is normal.

1- Up to one-third of the dissected surface is covered by abnormal cartilage.

2- One -third to half of the dissected surface is abnormal

3- More than half or the entire dissected surface is abnormal.

After measuring TD, tibia bones were placed in boiling water for 3 minutes and surrounding meat and connective tissues were subsequently cleaned. The outer dimensions of the tibia were determined at two points at midshaft using the Vernire calipers. After that, tibia bones were dried in air for 7 days and bone fragments were fat extracted by diethyl ether for 48-hrs. Then they were putt in a Muffle furnace at low temperature $\left(70{ }^{\circ} \mathrm{C}\right)$ for $24-\mathrm{hrs}$ to maintain the mineral contents from being lost. After that, the furnace temperature was increased to reach $600^{\circ}$ $\mathrm{C}$ for 3 - hrs and bone ash content was weighed and prepared for $\mathrm{Ca}$ and $\mathrm{Ph}$ percentages determination according to AOAC (1994). The $\mathrm{Ca}$ and $\mathrm{Ph}$ percentages were determined by atomic absorption spectrometer apparatus $\left(\mathrm{SK}_{1}\right.$, Power input, A.H. Series, Ty-Solar S4, SN ge710602).

\section{Blood sampling:}

Approximately $3.0 \mathrm{~mL}$ of blood was collected from alive 6 females and 6 males from the jugular vein for each treatment alone in the morning, following 8-hrs of feed deprivation. Each blood sample from each individual was divided into two samples in Eppendorf tubes. One was heparinized test tube by using Ethylenediamine-tetraacetate (EDTA) as an anticoagulant to study blood hematological parameters including Packed Cell Volume (PCV), hemoglobin (Hb), white blood cells (WBCs) and red blood cells (RBCs). The other was non-heparinized to study blood biochemical constituents (total lipids, triglycerides and cholesterol) and hormone assays (triiodthyronine, thyroxin and corticosterone). The samples were kept at $37{ }^{\circ} \mathrm{C}$ for 30 minutes and serum was separated by centrifuging the tube contents at $3000 \mathrm{rpm}$ for 15 minutes. Serum samples were stored in a deep freezer at $-20^{\circ} \mathrm{C}$ until the time of chemical analyses were carried out.

\section{Hematological parameters: Packed Cell Volume (PCV) and hemoglobin (Hb):}

Packed cell volume (PCV) was determined by microhaematocrit method as described by Akpa et al. (2007). The hemoglobin concentration, expressed in $\mathrm{g} / 100 \mathrm{~mL}$, was determined by dividing PCV value by 3 (Schalm et al., 1975).

Blood cells: Total WBCs and RBCs counts were made using a Neubauer haemocytometer with a dilution fluid (1:200) containing Gentian Violet and Brilliant Cresyl Blue according to the methods described by Natt and Herrick (1952). For the total and the differential counts blood smears were made and stained with a Diff-Quick stain set (Baxter Scientific, McGaw, IL), which is a modified Wright Giemsa stain. One drop of blood was being smeared on each of two glass slides. The smears were stained using MayGrunwald and Giemsa attains (Lucas and Jamroz, 1961), approximately 2 to 4-hrs after fixation with methyl alcohol. One hundred leukocytes, including granular (hetrophils, eosinophils and basophiles) and nongranular (lymphocyte and Monocyte) were counted on one slide for each bird, and the relative proportion of $\mathrm{H} / \mathrm{L}$ ratio was calculated in order to know the effect of SKD feeding regimes on the health and well being of the birds according to Gross and Siegel (1983). The hematocrit indices such as mean corpuscular volume (MCV), mean corpuscular hemoglobin $(\mathrm{MCH})$ and mean corpuscular hemoglobin concentration (MCHC) were calculated from RBCs count, $\mathrm{PCV}$ and $\mathrm{Hb}$ values.

\section{Serum biochemistry and hormone assays:}

Serum samples were used to determine total lipids, triglycerides and cholesterol according to Zollner and Kirsch (1962). Glucose was 
determined calorimetrically according to Trinder (1969) using spectrophotometer (Model 722 GRATING) by using glucose kit enzymatic colorimetric method (GOD-PAP, Cat No., T25981100T), Diamond Company, Stanbio Laboratory, Pastier Lab. Diagnostic and Biodiaquastic Company. Serum triiodthyronine (T3) and thyroxin (T4) were determined according to Ellis and Ekins, 1975) with commercial human enzyme immunoassay kit. The procedures followed the manufacturer's instruction. Serum corticosterone levels were determined by radioimunoassy (Durschlag et al., 1996).

\section{Feed cost:}

The economical efficiency and relative economical efficiency were calculated according to both the market selling price of one-kg feed and the prevailing market selling price of one quail at 43 days of age. Net revenue was calculated by subtracting total cost from total revenue. The relative economical returns were calculated relative to the control group.

\section{Data analysis:}

Data analysis was performed using General Linear Models (GLM) procedure of SPSS software program package (SPSS, 2005). All data were analyzed based on a completely randomized design using one way ANOVA. All percentages were first transformed to arcsine to approximate normal distribution before ANOVA. Data were presented as means \pm SEM. When the treatment effect was significant at $p \leq 0.05$, Tukey's test was applied to identify significant differences among groups. All statements of significance are based on testing at $p \leq 0.05$. All obtained data were analyzed by using the following Model:

$\boldsymbol{Y}_{i j}=\boldsymbol{u}+\boldsymbol{S}_{i}+\boldsymbol{e}_{i j}$, Where, $\boldsymbol{Y}_{i j}=$ is the analyzed measurement, u $=$ is the overall mean, $S_{i}=$ is the effect of SKD feeding regimes $(i,=1 \ldots 4)$ and $e_{i j}$ $=$ random error.

\section{RESULTS}

\section{Growth performance:}

Productive performance and mortality rate as affected by SKD feeding regimes are presented in Table 2. Results indicated that no significant differences for LBW were observed among the treatment groups at the beginning of experiment. At the mid growing period, at 25 days of age, CAL group had $(\mathrm{p} \leq 0.05)$ higher LBW compared with SKD treatment groups. While at the end of growing period, 43 day of age, similar LBW were observed among all the experimental groups.

Concerning BWG from 7 to 25 days of age, CAL group had significantly $(\mathrm{p} \leq 0.05)$ higher BWG than the other groups. This was followed, in a significant decreasing order, by quail subjected to $\mathrm{SKD}_{2}, \mathrm{SKD}_{4}$ and $\mathrm{SKD}_{6}$ respectively. However, from 26 to 43 days of age BWG was higher for the SKD feeding groups compared with the CAL group. During the whole period, 7 to 43 days of age, similar BWG was observed among all the treatment groups.

Subjecting quail to SKD feeding regimes causes a significant $(\mathrm{p} \leq 0.05)$ reduction in feed intake (FI) during the different periods of the experiment compared with the ad libitum group. Feed conversion ratio (FCR) observed during 7 to 25 days of age for quail subjected to $\mathrm{SKD}_{2}$, $\mathrm{SKD}_{4}$ and $\mathrm{SKD}_{6}$ had worst FCR compared to the CAL group. During the later periods (26 to 43 and 7 to 43 days of age), FCR was better for SKD feeding groups in comparison with the CAL group. Mortality rate, including metabolic and non metabolic disorders was significantly $(\mathrm{p} \leq 0.05)$ reduced, when quail were subjected to different SKD feeding regimes compared with quail fed ad libitum.

\section{Carcass characteristics:}

Results of carcass characteristics measured at 43 days of age are given in Table3. Subjecting quail to different SKD feeding regimes significantly $(\mathrm{p} \leq 0.05)$ affect all their relative carcass characteristics, except for dressing weight percentage. The relative total edible parts were significantly $(\mathrm{p} \leq 0.05)$ higher for quail subjected to $\mathrm{SKD}_{2}, \mathrm{SKD}_{4}$ and $\mathrm{SKD}_{6}$ than the CAL group. While, total inedible parts, showed a reverse trend, where it was higher for the CAL group in comparison with SKD feeding regimes. However, abdominal fat percentages were significantly $(\mathrm{p} \leq 0.05)$ reduced by using the SKD feeding regimes. Small intestine and cecum length were longer for quail subjected to $\mathrm{SKD}_{2}$, $\mathrm{SKD}_{4}$ and $\mathrm{SKD}_{6}$ compared with those fed ad libitum.

\section{Carcass and liver composition:}

Carcass and liver composition were expressed as percentages of dry matter basis (Table 4). It's appeared that DM, CP and ash percentages were higher $(\mathrm{p} \leq 0.05)$ in quail carcass subjected to $\mathrm{SKD}_{6}$, followed by $\mathrm{SKD}_{4}$ and $\mathrm{SKD}_{2}$ groups respectively, while the CAL group had lower values. However, the MO and EE percentages were lower for the SKD feeding regimes compared with the CAL group. It's clear that the MO, EE and NFE were lower for SKD feeding regimes, while $\mathrm{DM}, \mathrm{CP}$ and ash were higher. Concerning liver composition, no significant differences were observed for MO, DM and ash due to SKD feeding regimes. While $\mathrm{CP}$ and $\mathrm{EE}$ percentages were lower $(p \leq 0.05)$ in the liver of quail fed ad libitum compared with SKD treatment groups.

\section{Tibia bone measurements:}

Tibia bone measurements are presented in Table 5. Tibia weight $(\mathrm{g})$, length $(\mathrm{cm})$, tibia ash\% 
and tibia $\mathrm{Ca}$ (\% of ash) were significantly $(p \leq 0.05)$ higher for quail subjected to $\mathrm{SKD}_{2}$, $\mathrm{SKD}_{4}$ and $\mathrm{SKD}_{6}$ feeding groups compared with CAL the group. Tibia width $(\mathrm{cm})$ and tibia $\mathrm{Ph}(\%$ of ash) did not differ among the treatment groups. The incidence of TD phenomenon was less $(p \leq 0.05)$ for the quail subjected to $S K D$ feeding regimes as compared to the control group.

\section{Blood constituents: \\ Hematological parameters:}

The WBCs, RBCs, PCV and total $\mathrm{Hb}$ were significantly $(p \leq 0.05)$ higher in quail blood under progressive SKD feeding regimes (Table 6). Changes in these parameters appeared to be higher in the blood of quail that skipped for 6 days $\left(\mathrm{SKD}_{6}\right)$ compared with the CAL group. Differential cell counts, including hetrophils and lymphcytes percentages, were higher for SKD groups than the ad libitum group. However, subjecting quail to SKD feeding regimes, especially with those skipped for 6 days $\left(\mathrm{SKD}_{6}\right)$ had elevated $\mathrm{H} / \mathrm{L}$ ratio. The increase of $\mathrm{H} / \mathrm{L}$ ratio was considered an indicator of stress in quail. No significant differences were noted for $\mathrm{MCV}$, $\mathrm{MCH}$ and $\mathrm{MCHC}$ due to SKD feeding regimes.

Biochemical constituents and hormone assays:

Implementation of SKD feeding regimes increased total lipids, triglycerides and cholesterol contents in quail blood compared with the ad libitum group. However, blood glucose levels did not differ among the experimental groups and remained fairly constant throughout the experiment. Hormone assays data indicated that T3 and T4 levels gradually $(\mathrm{p} \leq 0.05)$ decreased with the progressive increase in the number of days with no feeding. However, corticosterone concentration increased compared with the CAL group.

\section{Economical efficiency:}

The economical efficiency and relative economical efficiency were calculated according to both the market selling price of one-kg feed and the prevailing market selling price of one quail at 43 days of age. Regarding the economical point of view, the data illustrated in Table 7 indicated that the practice of SKD feeding regimes improves the economical efficiency and relative economical efficiency, especially with $\mathrm{SKD}_{6}$ compared with the CAL group. Hereupon, there are considerable costs saving with the practice of subjecting feeding for up to 6 days, when compared with quail fed every day.

\section{DISSCUSION}

\section{Growth performance:}

It appears that skip-a-day (SKD) feeding regimes during mid period of life negatively affect live body weight (LBW) and body weight gain (BWG), where the more severe attained at 25 day of age. This could be explained in terms of lower feed intake, and subsequently lower nutrient intake. The lower feed intake was attributed to the smaller amount of feed offered. These results are in agreement with the finding of Oyedeji and Atteh (2005) and Rezaeei et al. (2006). They reported that feed restriction or SKD feed removal decreased early growth of chickens. Also, Hassan et al. (2003) indicated that feed restriction of female Japanese quail causes a reduction of LBW from 3 to 5 weeks of age. However, male weights were depressed only during the most severe restriction at 4 and 5 weeks.

While, at the end of growing period (43 day of age), similar LBW and BWG were observed among the experimental groups. This was attributed to the compensatory growth phenomenon, which occurs after a period of under nutrition or recovery from illness ( $\mathrm{Yu}$ and Robinson, 1992). Compensatory growth occurs after a growth deficit or growth retardation resulting from a limit nutrient intake or early feed restriction (Wilson and Osbourm, 1960). Alternatively, due to their early age at sexual maturity, quail may exhibit accelerated growth following early feed restriction in order to obtain the minimum body weight for sexual maturity (Sabine et al., 1995). Finally LBW of SKD feeding regimes of quail was compensated for by day 43 of age. This is similar to Dozier et al. (2002) reported that broiler chickens subjected to 4 days of feed removal, in a SKD program, had the same LBW as those of birds fed ad libitum. They added that broilers subjected to SKD regimes for 4 and 6 days subsequently gave greater average daily gain than broiler fed $a d$ libitum, although average daily gain was greater in birds skipped 6 day than 4 day after the resumption of feeding ad libitum (0.145 vs. 0.142 $\mathrm{Ib} / \mathrm{d}$ ), it increased more in $\mathrm{R}_{4}$ than $\mathrm{R}_{6}$, when expressed relative to ad libitum (6.8 vs. 5.1\%). Complete compensatory growth occurred, when feed removal periods were used. In other reports, Novel et al. (2008) indicated that chickens on 75\% ad libitum feeding attained complete LBW compensation with those on ad libitum feeding at the age of 42 days.

In the present study, Japanese quail subjected to $\mathrm{SKD}_{2}, \mathrm{SKD}_{4}$ and $\mathrm{SKD}_{6}$ consumed less feed compared to quail fed ad libitum. The lower feed intake was attributed to smaller amounts of feed offered. This finding was similar to the results obtained by Dozier et al. (2003) reported lower FI of broilers subjected to early SKD feed removal compared with birds feed ad libitum. Novel et al. (2009) illustrated that increasing the level of feed restriction reduced FI of broiler chickens. Osman et al. (2011) indicated that FI was progressively decreased $(\mathrm{p} \leq 0.05)$ with increasing feed deprivation during the starting 
period from 1 to 3 weeks. The same trend was also present for whole experimental period from 1 to 6 weeks of age. The depression in FI represented about $2.55,3.83,5.6$ and $8.36 \%$ for broiler fasted for $4,6,8$ and $10 \mathrm{hrs} /$ day, respectively compared with the ad libitum group during the whole experimental period.

In the present study, FCR during earlier ages (7 to 25 days) was the worst. While, in the later periods (26 to 43 and 7 to 43 days of age), better FCR had been observed for the SKD groups compared with the CAL counterparts. The improvement in FCR for the restricted birds, based on the fact of the activities of the enzymes associated with hepatic lipogenesis, is depressed during the nutrient restriction periods, but after refeeding their activity is increased (Mc-Murtry et al., 1988). As a consequence the FCR improved for the Japanese quail exposed to SKD feeding regimes. Another reason for the improvement of FCR is the increased appetite following refeeding which is largely responsible for improved FCR associated with compensatory growth (Osbourn and Wilson, 1960). These results are in agreement with Hassanabadi and Nassiri (2006). They indicated that FCR has been improved with feed restriction program compared with birds fed ad libitum. Novel et al. (2008) found that feed restriction of broiler chickens resulted in a better FCR as compared with birds fed ad libitum.

In the present study SKD feeding regimes resulted in reduced mortality rates, including metabolic and nonmetabolic disorder, where no mortality occurred by the $\mathrm{SKD}_{6}$ treatment compared with the CAL group. Slowing growth rate in early age due to SKD feeding regimes may reduce mortality afterwards. These results are similar to those of Arce et al. (1992) who observed significant reduction in ascites induced mortality in broilers subjected to SKD feed regimens for long periods. Ozkan et al. (2006) and Line et al. (2008) indicated that metabolic and total mortality of broilers decreased, when feed restricted compared with control fed ad libitum. In general, the better performance of Japanese quail in the present study could be explained in terms of better FCR.

\section{Carcass characteristics:}

The present results indicated that at 43 days of age Japanese quail subjected to different SKD feeding regimes attained similar LBW to those fed ad libitum feeding. However, skipped groups had higher liver, heart, gizzard, edible parts and total edible parts percentages than those on the ad libitum feeding. Although quail skipped for 6 days $\left(\mathrm{SKD}_{6}\right)$ had the higher percentages of these parts than other SKD or CAL groups. The increase of liver weight for SKD groups was mainly due to glycogen and water accumulation in the liver rather than higher lipid content
(Katanbaf et al., 1989a). Dressing parentages were similar among the treatment groups. However, quail fed ad libitum had higher total inedible parts and abdominal fat percentages than those subjected to different SKD feeding regimes. The reduction in abdominal fat may be beneficial for the consumer. However, intestine and cecum length increased due to the application of SKD feeding regimes. This is similar to results reported by Zubair and Lesson (1996) and Hassanabadi and Nassiri (2006) who found that feed restriction programs causes reduction in abdominal fat percentage in broiler chicken compared with those fed ad libitum. Dozier et al. (2002) reported that carcass weights were not reduced, when broiler chickens skipped feeding for 2 to 4 days at 54 days of age. However, the present results are contrary to the findings of Novel et al. (2008) indicated that the level of feed restriction had no effect on dressing, gizzard, and liver weight percentages of broilers chickens. While, broiler on 75 and $50 \%$ of ad libitum feeding had lower fat pad weight than those on ad libitum feeding. Also, Novel et al. (2009) showed that the level of feed restriction had no effect on dressing percentage and intestine length as well as on weights of wings, fat pad, gizzard and liver. Osman et al. (2011) reported that feed restriction had insignificant effect on carcass weight and dressing percentages, while abdominal fat percentages decreased.

\section{Carcass and liver composition:}

In this study, bodies of Japanese quail that were subjected to $\mathrm{SKD}_{2}, \mathrm{SKD}_{4}$ and $\mathrm{SKD}_{6}$ had higher DM, CP and ash contents than CAL group at 43 days of age. Moisture and ether extract percentages were higher in the bodies of quail fed ad libitum than those subjected to different SKD feeding regimes. These results suggested that carcass $\mathrm{CP}$ and $\mathrm{EE}$ were the limiting factors affecting the composition of meat. These findings are in agreement with Plavnik and Hurwitz (1990) and Hassanabadi and Nassiri (2006) who found that carcass fat content was reduced in feed restricted birds compared with those fed $\mathrm{ad}$ libitum. In contrast, Shariatmadari and Moghadamian (2007) found that feed restriction did not have any significant effect on carcass composition (protein, fat, ash and dry matter). However, in the present study, liver composition was also partly affected by feeding regimes especially with respect of $\mathrm{CP}$ and $\mathrm{EE}$, where quail subjected to SKD feeding regimes generally had higher values than the CAL group. The increase of $\mathrm{EE}$ in the liver may be attributed to the increase of liver weight in quail subjected to SKD which is a result of higher lipid level (Katanbf et al., 1989b). Also, the liver is the major site of fatty acid synthesis in the chickens (Hermier, 1997). However, nutritional alteration 
of lipogenesis in birds is generally achieved either by fasting and refeeding or by altering energy-protein ratios in the diet (Rosebrough, 2000). These results are in accordance with De Beer and Coon (2009) who found that total fat in the liver was generally higher in birds subjected to different SKD feeding program than birds fed every day due to increased liver weight. Lamosova et al. (2004) indicated that total lipid content in the liver of female Japanese quail decreased significantly after 12, 24 as well as after $48 \mathrm{hr}$ of fasting.

\section{Tibia bone measurements:}

It's evident from the obtained results that SKD feeding regimes, as a method, was efficient to improve tibia weight, length, width, bone ash percentage and tibia calcium (\% of ash). Bone ash percentage increased by the application of SKD feeding regimes, where feed deprivation may have resulted in more retention of calcium in the bone (Elliot and Edwards, 1994). The TD incidence progressively decreased for SKD feeding regimes groups in comparison with quail fed ad libitum. The decreased in TD incidence may be due to the fact that feed deprivation may reduce the circulating level of insulin like growth factor (IGF-I) resulted in more retention of calcium in the bone, which appear to be an effective way to prevent TD in broiler chickens (Roberson et al., 2002). No effect of SKD feeding regimes had been observed on tibia width (cm) and tibia $\mathrm{Ph} \%$. These findings agreed with Robinson et al. (1992) who found that restricting FI of broiler at the second week, post-hatch, significantly reduced skeletal problems associated with early growth. Roberson et al. (2002) indicated that the incidence of TD lesions decreased by 50 to $80 \%$ when feeding time was restricted, and bone ash increased compared to birds fed ad libitum.

\section{Blood constituents: \\ Hematological parameters:}

From the results presented in Table 6, it was clear that SKD feeding regimes increased $\mathrm{WBC}_{\mathrm{S}}$, RBCs count, PCV, Hb, hetrophils and lymphocytes percentages and $\mathrm{H} / \mathrm{L}$ ratio. While, $\mathrm{MCV}, \mathrm{MCH}$ and MCHC did not differ among the experimental groups. The increase of $\mathrm{H} / \mathrm{L}$ ratio for the SKD groups is an indicator of stress. The elevation of WBCs and H/L ratio ware are the most accepted indicator of stress (Campo and Davila, 2002), and may reflect a stress response in quail subjected to SKD feeding regimes. Also hetrophils counts have already been suggested as a good means of assessing stress in birds (Wolford and Ringer, 1962). In this respect, Gross and Siegel (1983) indicated that feed deprivation is known to shift the proportion from lymphcytes to hetrophils. On the contrary, Totzke et al. (1999) showed that hematocrit and hemoglobin decreased in fasting birds as a result of stress. Also, they added that lymphcytes and hetrophils were, in particular, applicable to stress induced by feed deprivation. Hocking et al., (1993) indicated that broiler breeders subjected to feed restriction are stressed. Theses results are in agreement with those of Maxwell et al. (1990) indicated that $\mathrm{H} / \mathrm{L}$ ratio increased in broilers maintained on a prolonged program of feed restriction. Hassan et al. (2003) noted that feed restriction increased the percentage of hetrophils and basophiles and the hetrophils /lymphocytes ratio in quail, whereas the percentage of lymphocytes and eosinophils decreased. However, Junqueira et al. (2003) found that hematological parameters of broilers were not affected by feed restriction.

\section{Biochemical parameters and hormone assays:}

In the present study, SKD feeding regimes caused an increase of lipid fractions including total lipids, triglycerides and cholesterol. This may be attributed to that skipped feeding birds tended to maintain a normal body composition at the expense of growth (Nair and Nitsan, 1979). The increase of triglycerides was indicative of the mobilization of fatty substrate during fasting. Also, cholesterol as an anabolic precursor (steroids, bile acid, membranes) appeared to be not affected by the increased lipid catabolism during starvation (Totzke et al., 1999). Contrary, Lamosova et al. (2004) indicated that the concentration of total lipids and triacylglycerol in plasma of female quail gradually decreased with time of fasting. A significant decrease was found after 12, 24 and $48 \mathrm{hrs}$ of fasting. However, the present results indicated that total glucose was not affected by SKD feeding regimes. This is because glucose levels are regulated by hormonal control and are normally maintained even under fasting condition in most birds species (Totzke et al., 1998). This finding is not in agreement with Nair and Nitsan (1979) who found that the increase in plasma glucose in feed restricted birds may be because they tended to maintain a normal body composition at the expense of growth. Le Maho et al. (1981) indicated that glucose concentration in geese was maintained at high level through fasting. While, Van et al. (1999) showed that feed withdrawal causes a reduction in the concentration of glucose in the blood of broilers and the reduction continued until $10 \mathrm{hrs}$ of deprivation, after which the level stabilized or even increased slightly.

In the present study, it was noted that T3 and T4 gradually $(p \leq 0.05)$ decreased with progressive SKD feeding regimes. A decrease of thyroid hormone is a well-known adaptation in mammals and birds during fasting (Totzke, 1996). The decrease is usually explained by a reduction of the metabolic rate, which results in sparing of energy reserves. These findings agree with Mc-Murtry et al. (1988) who found that 
thyroid hormone concentration decreased after feed restriction period but increased and reach the control level by refeeding. The influence of fasting on corticosterone level is less clear, where corticosterone concentration increased with application of SKD feeding regimes compared with the CAL group. The increase of corticosterone level was an indication of stress of quail (Campo and Davila, 2002). Our results are in agreement with those reported by Harvy and Klandorf (1983). They indicated that, in most birds species, an increase of corticosterone has been described during short-term feed restriction. Julian and John (2009) indicate that plasma concentration of corticosterone, a glucocorticoid hormone, have been reported to increase during fasting in some species of birds. They found that corticosterone can stimulate feed intake in quail following a period of feed deprivation.

\section{Economical efficiency:}

From an economical point of view, it appears that SKD feeding regimes were useful method to decrease feed cost during growing period of Japanese quail. Where, SKD feeding regimes gave the highest economical and relative economical efficiency values compared with quail fed ad libitum. This may be attributed to the reduction in the total cost of feed, and also, may be due to amelioration for FI and BWG. Hereupon, there are considerable costs evaluating with practice of SKD feeding regimes, when compared with CAL group. Our results were similar to those of Osman et al. (2011) who observed that the total cost of diet / bird was progressively decreased $(\mathrm{p} \leq 0.05)$ with increasing feed deprivation vs. ad libitum. The reduction in the cost of diet was mainly due to decreased feed intake with increasing fasting time. Also Hassanien (2011) showed that feed restriction significantly reduced consumption and the same time improving economic efficiency of broiler chickens.

\section{CONCLUSION AND APPLICATION}

1-The use of skip-a-day feeding regimes improve FCR consequently, LBW and BWG were not affected negatively during the growing period.

2- The major benefit seen with the application of SKD feeding regimes is a reduction in mortality rate. This may provide an economical benefit by allowing more birds at the end of the growing period.

3- Skip-a-day feeding regime increased response to stress as judged by the increase of $\mathrm{H} / \mathrm{L}$ ratio and corticosterone concentration.

4- In this study, it seemed likely that SKD feeding regimes may offer an economical advantage over ad libitum feeding regimes. It may, therefore, be a useful nutritional strategy to reduce the cost of the diet without any negative effect on performance.

\section{REFERANCES}

A.O.A.C., 1994. Association Of Official Analytical Chemists, "Official Methods of Analysis $15^{\text {th }} \mathrm{Ed}$. Published by the A.O.A.C. Washington, DC., U. S. A.

Akpa, G.N.K., A. Koffi, M. R. Hassan, M. Kabir, S. Duru and S.M. Yashim, 2007. Effects of feed type, sex and plumage condition on tonic immobility and blood parameters in broilers. Intr. J. of Poult. Sci., 6(3): 218-222.

Arce, J., M. Berger and C.L. Coello, (1992). Control of ascites syndrome by feed restriction techniques. J. Appl. Poult. Resh. $1: 1-5$.

Campo, J. L. and S. G. Davila, (2002). Effect of photoperiod on heterophil to lymphocyte ratio and tonic immobility duration of chickens. Poult. Sci., 81: 1637-1639.

De Beer, M. and C. N. Coon, (2009).The effect of feed restriction and growth curves on reproductive performance, in vitrolipogenesis and hetrophils to lymphocyte ratios in broiler breeder hens. Int. J. of Poult. Sci., 8 (4): 373-388.

Dozier, W. A., R. J. Lien; J. B. Hess, D. S. F. Bilgili, R. W. Gordon, C. P. Laster and S. L. Vieira, (2002). Effects of early skip-a-day feed removal on broiler live performance and carcass yield. J. Appl. Poult. Res., 11: 297303.

Dozier, W. A., R. J. Lien, J. B. Hess and S. F. Bilgili, (2003). Influence of early skip-a-day feed removal on live performance and carcass yield of broilers of different sexes and strain sources. J. Appl. Poult. Res., 12: 439-448.

Durschlag, M., H. Wurbel, M. Stauffacher and D. Von Holst, (1996). Repeated blood collection in the laboratory mouse by tail incision: modification of old technique. Physiol. Behav. 60: 1565-1568.

Edwards, Jr. H. M., (1984). Studies on the etiology of tibial dyschondroplasia in chickens. J. of Nutr., 114:1001-1013.

Elliot, M. A. and H. M. Edwards, Jr., (1994). Effect of genetic strain, calcium, and feed withdrawal on growth, tibial dyschondroplasia, plasma1.25 dihydrocholecalciferol and plasma 25hydroxycholecalciferol in sixteen-day old chickens. Poult. Sci., 73: 509-519.

Ellis, S. M. and R. P. Ekins, (1975).The radioimmunoassay of serum triiodthyronine and thyroxin radioimunoassy in clinical Biochemistry CA, Pasternak, ed. (LondonHeyden): 187-94.

Govaerts, T., G. Room, J. Buyse, M. Lippens, G. De Groote and E. Deucypere, (2000). Early and temporary quantitive food restriction of broiler chickens.2. Effcet on algometric growth and growth hormone secretion. $\mathrm{Br}$. Poult. Sci., 41: 355-362. 
Gross, W. B. and P.B. Siegel, (1983). Evaluation of the hetrophil:lymphocyte ratio as a measure of stress in chickens. Avian Dis., 27: 972-979.

Harvy, S. and H. Klandorf, (1983). Reduced adrenocortical function and increased thyroid function in fasted and refed chickens. J. Endocrinology, 98: 129-135.

Hassanabadi, A. and H. M. Nassiri, (2006). Effect of early feed restriction on performance chractristics and serum thyroxin of broiler chickens. Intr. J. of Poult. Sci., 5(12): 1156-1159.

Hassan, S.M., M. E. Mady, A. L. Cartwright, H. M. Sabri and M. S. Mobarak, (2003). Effect of early feed restriction on reproductive performance in Japanese quail (Coturnix coturnix Japonica). Poult. Sc., 82: 11631169.

Hassanien, H.H.M., (2011). Productive performance of broiler chickens as affected by feed restriction systems. Asian J. of Poult. Sci., 5(1): 21-27.

Hermier, D. (1997). Lipoprotein metabolism and fattening in poultry. J. Nutr., 127: 805-808.

Hocking, P. M., M. H. Maxwell and M. A. Mitchell, (1993). Welfare assessment of broiler breeder and layer females subjected to food restriction and limited access to water during rearing. Br. Poult. Sci., 43: 443-458.

Julian, P. W. and F. John, (2009). Effects of corticosterone treatment on response to fasting in Japanese quail. Comp. Bioch. and Physiol., 54 (2): 211-215.

Junqueira, O. M., L. E. C. Fonseca, L. F. Araujo, K. F. Duarte, C. S. Araujo, S. da and E. A. P. Rodrigues, (2003). Feed restriction on performance and blood parameters of broilers fed diets with different sodium levels. Revista Brasileria de Ciencia Avicola 5(2): 55-59.

Katanbaf, M. N., E. A. Dunnington and P. M. Siegel, 1989a. Restricted feeding in early and late feathering chickens.1- Growth and physiological responses. Poult. Sci., 68:344351.

Katanbaf, M. N., E. A. Dunnington and P. M. Siegel, (1989b). Restricted feeding in early and late feathering chickens.2. Reproductive responses. Poult. Sci., 68: 352-358.

Lamosova, D.; M. MacaJova and M. Zeman, (2004). Effects of short-term fasting on selected physiological functions in adult male and female Japanese quail. ACTA VET. BRNO., 73: 9-16.

Le Maho,Y., H.V.U. Vankha, H. Koubi, G. Dewasmes, J. Girard, P. Ferri and M. Cagnard, 1981. Body composition, energy expenditure and plasma metabolites in longterm fasting geese. Am. J. Physiol., 241: 342354.

Lee, K. H. and S. Lesson, (2001). Performance of broilers fed limited quantities of feed or nutrients during seven to fourteen days of age. Poult. Sci., 80: 446-454.

Line, R. J., K. S. Macklin, J. B. Hess, W. A. Dozier, I.I.I and S. F. Bilgili, (2008). Effects of early skip-a-day feed removal and litter material on broiler live and processing performance and litter bacterial levels. Int. J. of Poult. Sci., 7(2):110-116.

Lippens, M., G. Room, G. De Groote and E. Decuypere, (2000). Early and temporary quantitative feed restriction of broiler chickens.1.Effects on performance characteristics, mortality and meat quality. Br. Poult. Sci., 343-354.

Lucas, A. M. and C. Jamroz, (1961). Atlas of Avian hematology Agriculture Monograph 25.USDA, Washingtohn, DC.

Mady, M. E., (1976). Some physiological studied on Japanese quail (Coturnix coturnix japonica) under Egyptian environmental conditions. M.Sc. Thesis, Ain Shams Uni., Faculty of Agriculture.

Mady, M. E., (1981). Some factors affecting reproductive efficiency and productivity of Japanese quail under Egyptian environmental conditions. Ph.D. Thesis, Ain Shams Uni, Faculty of Agriculture.

Maxwell, M. H., G. W. Robertson, S. Spence and C. C. Mc-Corquodole, (1990). Comparison of haematological values in restricted and adlibitum feed fowls: White blood cells and thromobcytes. Br. Poult. Sci., 31: 399-405.

Mazzuco, H.; A. L. Guidone and F. R. Jaenisch, (2000). Efeito da restricao alimentar qualitative sobre oganho comensatorio em frangos de corte. Pesquisa Agropecuaria Brasileira 35: 543-549

Mc-Murtry, J. P., I. Plavnik, R. W. Rosebrough, N. C. Steels and J. A. Proudman, (1988). Effect of early feed restriction in male broiler chicks on plasma- metabolic hormones during feed restriction and accelerated growth. Comp. Biochem. and Physiol., 91: 67-70.

Nair,I. and Z. Nitsan, (1979). Metabolic and anatomical adaptation of light bodies chicks to intermittent feeding. Br. Poult.Sci., 20: 6071.

Natt, M. P. and C. A. Herrick, (1952). Anew blood diluents for counting the erythrocytes and leucocytes of chicken. Poult. Sci., 31: 735-738.

Novel, D.J., J.W. Ngambi, D. Norris and C.A. Mbajiorgu, 2008. Effect of sex, level and period of feed restriction during the starter stage on productivity and carcass characteristics of Rose 308 broiler chickens in South Africa. Intr. J. of Poult. Sci., 7(6):530537.

Novel, D. J., J. W. Ngambi, D. Norris and C. A. Mbajiorgu, (2009). Effect of different feed restriction regimes during the starter stage on productivity and carcass characteristics of 
male and female Ross 308 broiler chickens. Intr. J. of Poult. Sci., 8(1): 35-39.

Nutrient requirements of poultry (N.R.C) (1994). $9^{\text {th }}$ ed., National Academy of Science, National Research Council. Washington, D. C. U.S. A.

Osbourn, D. F. and P. N. Wilson, (1960). Effects of different patterns of allocation of a restricted quantity of food upon the growth and development of cockerels. J. Agric. Sci., 54: 274-289.

Osman, A. M. A., M. A. Toson, S. A. AbdelLatif, H. H. M.Hassanien, T. M. A. Marwan, (2011). Effect of feed restriction on productive performance of broiler chicks. Egypt. Poult. Sci., 31(1): 19-27.

Oyedeji, J. O. and J. O. Atteh, (2005). Response of broilers to feeding manipulation. Int. J. Poult. Sci., 4: 91-95

Ozkan, S., I. Plavnik and S.Yahav, (2006). Effects of early feed restriction on performance and ascites development in broiler chickens subsequently raised at low ambient temperature. J. Appl. Poult. Sci., 15: 9-19.

Plavnik,I. and S. Hurwitz, (1990). Performance of broiler chickens and turkey poults subjected to feed restriction or to feeding of low protein or low -sodium diets at an early age. Poult. Sci., 96: 945-952.

Rezaeei, M., A. Teimouri, J. Pourreza, H. Sayyahzadeh and P. W. Waldropup, (2006). Effect of diet dilution in the starter period on performance and carcass characteristics of broiler chicks. J. Central European Agric., 7: 63-70.

Roberson, K. D.; C. H. Hill and P. R. Ferket, (2002). Effect of intermittent feed deprivation on plasma insulin like growth factor-1 and tibial dyschondroplasia in broiler chicks. Intr. J. of Poult.Sci., 1(1): 22-25.

Robinson, F. E., H. L. Classen, J. A. Hanson and D. K. Onderka, (1992). Growth performance, feed efficiency and the incidence of skeletal and metabolic diseases in full-fed and feed restricted broiler and roaster chickens. J. App. Poult. Rese.1: 33-41.

Roseberough, R.W., (2000). Dietary protein levels and the responses of broilers to single or repeated cycles of fasting and refeeding. Nutr. Res., 20: 877-886

Sabine, G., G. Henrich and H.L. Marks, 1995. Effects of feed restriction on growth and reproduction in random breed and selected lines of Japanese quail. Poult. Sci. 74:402406.

Sartori, D. R. S., R. H. Migliorini; J. A. S. Veiga, J. L. Moura, I. C. Kettelhut and C. Linder (1995). Metabolic adaptation induced by long-term fasting in quail. Com. Bioch. Physiol., IIIA: 487-493.
Schalm, J.W., N.C. Jain and E.J. Carol, (1975). Veterinary Haematology. $3^{\text {ed }}$ Edn. Lea and Febriger. Philadelphia USA, pp: 15-81.

Shariatmadari, F. and A. A. Moghadamian, (2007). Effect of early feed restriction in combination with intermittent lighting during the natural Scotoperiod on performance of broiler chicken. J. Sci. and Technol. Agric. and Natur.Resour.11(40): 363-374.

SPSS for windows, Chicago, IL SPSS ${ }^{\circ}$. Computer Software 16.0, (2005). SPSS Inc., Headquarters. Wacker Drive, Chicago, Illinois 60606, USA. 233 pp.

Totzke, U., (1996). Klinisch. Chemische character isierung und endokrina Befunde zur zugzeeitlichen Fettdeposition der Gartengrasmucke (Sylvia borin). PhD Thesis. Univ. of Cologne, Germany.

Totzke, U., A.Hubinger and F. Bairlein, (1998). Glucose utilization rate and pancreatic hormone response to oral glucose loads are influenced by the migratory condition and fasting in the garden warbler (Sylvia borin). J. Endocrinology 158: 191-196.

Totzke,U., M. Fenske, O. Huppop, H. Rabbe and N.Schach, 1999. The influence of fasting on blood and plasma composition of Herring Gulls. Physiol. and Bioch. Zoology 72:426437.

Trinder, L., (1969). Determination of blood glucose using an oxidation peroxides system with a non carcinogen chromogen. Am. Clin. Biochem. 6: 24-27.

Van,P.G., H. G. M. Reimert, H. A. Goedhart, B. Engeli, T. G. Uijttenboogaart, (1999). The effect of feed withdrawal on broiler blood glucose and nonestretifed fatty acid levels, postmortem, liver $\mathrm{pH}$ values and carcass yield. Poult. Sci., 78: 569-573.

Wilson, P.N. and D. F. Osbourm, (1960). Compensatory growth after under nutrition in mammals and birds. Biol. Rev. 35: 325-363.

Wolford, J. H. and R. K. Ringer, (1962). Adrenal weight, adrenal ascorbic acid, adrenal cholesterol and differential leukocyte counts as physiological indicators of stressors agents in laying hens. Poult. Sci., 41: 1521-1529.

Yu, M. U., and F.E. Robinson, (1992). The application of short-term feed restriction to broiler chicken production. A. Review. J. App. Poult. Sci., 1: 147-153.

Zollner, N. and K. Kirsch, (1962). Uber the quantitive bestimmung von lipoiden (mik ro methode mittols der vielen naturlichen lipoiden allen bekannten plasma lipoiden) gemeinsamen suffophospho vitamin reaction. Zeitscrif Fur Die Gesante Experimental Medicine.135: 545-556.

Zubair, A. K. and S. Lesson, 1996. Changes in body composition and adipocyte cellularity of male broiler subjected to Varity degrees of early life restriction. Poult. Sci., 75: 719-728. 
Table 1. Composition of the used diet

\begin{tabular}{lc}
\hline \multicolumn{1}{c}{ Ingredients } & Quantity ( $\mathrm{kg})$ \\
\hline Ground yellow corn $(8.5 \%)$ & 55.55 \\
Soybean meal $(44 \%)$ & 30.50 \\
Gluten meal $(60 \%)$ & 09.72 \\
Wheat bran $(15.7 \%)$ & 01.00 \\
Calcium carbonate $\left(\mathrm{CaCo}_{3}\right)$ & 01.34 \\
Di-calcium phosphate $\left(\mathrm{Ca}_{2} \mathrm{HPO}_{4}\right)$ & 00.88 \\
Sodium chloride $(\mathrm{NaCl})$ & 00.25 \\
Choline chloride & 00.14 \\
DL-Methionine & 00.09 \\
L-Lysine $(\mathrm{Hcl})$ & 00.23 \\
Pre-mix* & 00.30 \\
\hline Total (kg) & 100.0 \\
\hline Calculated diet analysis: & 24.10 \\
Crude protein (\%) & 2913 \\
Metabolizable energy (kcal/kg) & 00.80 \\
Calcium (\%) & 00.31 \\
Available phosphorus (\%). & 02.59 \\
Ether extract (\%) & 03.24 \\
Crude fiber (\%) & 01.32 \\
Lysine (\%) & 00.54 \\
Methionine (\%) & 00.86 \\
Methionine + Systine (\%) & 02.16 \\
Price (LE/ kg)** & \\
*The premix (Vit\& Min) was added at a rate of 3kg per ton of diet and supplied as following (as mg or I.U. per kg of diet): \\
Vit A 12000 I.U., Vit D3 2000 I.U., Vit E 40 mg, Vit. K 34 mg, Vit. B 1 3 mg, Vit. B2 6 mg, Vit. B6 4 mg, Vit. B12 0.03 mg, \\
Niacin 30 mg, Biotin 0.08, mg, Pantothenic acid 12 mg, Folic acid 1.5 mg, Choline chloride 700 mg, Mn 80 mg, Cu 10 mg, Se. 0.2 \\
mg, Fe 40 mg, Zn 70 mg and Co.0.25mg. \\
**Price of one kg (LE) at time of experiment for different ingredients: Yellow corn 1.70, soybean meal 2.80, gluten 2.50, wheat bran \\
1.10, limestone 0.10, di-calcium phosphate 3.0, sodium chloride 0.25, choline chloride 2.0, methionine 25.0, lysine19.0 and \\
pr-mix 4.0.
\end{tabular}

Table 2. Growth performance and mortality rate of Japanese quail subjected to ad libitum or various SKD feeding regimes

\begin{tabular}{|c|c|c|c|c|c|c|}
\hline \multirow[b]{2}{*}{ Items } & \multicolumn{6}{|c|}{ SKD feeding regimes } \\
\hline & $\mathrm{CAL}^{1}$ & $\mathrm{SKD}_{2}{ }^{2}$ & $\mathrm{SKD}_{4}{ }^{3}$ & $\mathrm{SKD}_{6}{ }^{4}$ & $\begin{array}{l}\text { Pooled } \\
\text { SEM }^{5} \pm \\
\end{array}$ & Significance \\
\hline \multicolumn{7}{|l|}{$\begin{array}{l}\text { Live body weight }(\mathrm{g}) \\
\text { at: }\end{array}$} \\
\hline 7 days & 18.59 & 18.60 & 17.73 & 18.56 & 0.66 & $\mathrm{NS}^{6}$ \\
\hline 25 days & $93.60^{\mathrm{a}}$ & $86.21^{\mathrm{b}}$ & $75.16^{\mathrm{c}}$ & $67.17^{\mathrm{c}}$ & 2.61 & $*$ \\
\hline 43 days & 199.06 & 199.20 & 198.42 & 198.48 & 1.21 & NS \\
\hline \multicolumn{7}{|l|}{$\begin{array}{l}\text { Body weight gain }(\mathrm{g}) \\
\text { from: }\end{array}$} \\
\hline 7-25days & $75.01^{\mathrm{a}}$ & $67.61^{\mathrm{b}}$ & $57.43^{\mathrm{c}}$ & $48.61^{\mathrm{d}}$ & 2.59 & * \\
\hline 26-43 days & $105.46^{\mathrm{d}}$ & $112.99^{c}$ & $123.26^{\mathrm{b}}$ & $131.31^{\mathrm{a}}$ & 3.03 & $*$ \\
\hline 7-43 days & 180.47 & 180.60 & 180.69 & 179.92 & 1.60 & NS \\
\hline \multicolumn{7}{|l|}{$\begin{array}{l}\text { Feed intake( g/birds) } \\
\text { from: }\end{array}$} \\
\hline 7-25days & $243^{\mathrm{a}}$ & $237^{\mathrm{b}}$ & $232^{\mathrm{c}}$ & $225^{\mathrm{d}}$ & 2.39 & $*$ \\
\hline 26-43 days & $350^{\mathrm{a}}$ & $334^{\mathrm{b}}$ & $296^{\mathrm{c}}$ & $268^{d}$ & 8.29 & $*$ \\
\hline 7-43 days & $593^{\mathrm{a}}$ & $571^{\mathrm{b}}$ & $528^{\mathrm{c}}$ & $493^{d}$ & 9.99 & $*$ \\
\hline $\begin{array}{l}\text { Feed conversion ( } \mathrm{Kg} \\
\text { feed/Kg gain) from }\end{array}$ & & $3.51^{\mathrm{c}}$ & $4.04^{b}$ & $4.63^{\mathrm{a}}$ & 0.14 & $*$ \\
\hline $7-25$ days & $3.24^{\mathrm{d}}$ & $2.96^{\mathrm{b}}$ & $2.40^{\mathrm{c}}$ & $2.04^{\mathrm{d}}$ & 0.12 & $*$ \\
\hline 26-43days & $3.31^{\mathrm{a}}$ & $3.16^{\mathrm{b}}$ & $2.92^{\mathrm{c}}$ & $2.74^{\mathrm{d}}$ & 0.06 & $*$ \\
\hline $7-43$ days & $3.29^{\mathrm{a}}$ & & & & & \\
\hline mortality $\%$ & & & & & & \\
\hline Metabolic $^{7}$ & $(n=14 / 105) 13.33^{a}$ & $(n=11 / 105) 10.48$ & $(\mathrm{n}=11 / 105) 10.48^{\mathrm{b}}$ & $(\mathrm{n}=5 / 105) 4.76^{\mathrm{c}}$ & 0.66 & $*$ \\
\hline Nonmetabolic $^{8}$ & $(n=5 / 105) 4.76^{a}$ & $(\mathrm{n}=4 / 105) 3.81^{\mathrm{b}}$ & $(n=3 / 105) 2.86^{c}$ & $(\mathrm{n}=0 / 105) 0^{\mathrm{d}}$ & 0.51 & $*$ \\
\hline Total & $18.09^{\mathrm{a}}$ & $14.29^{\mathrm{b}}$ & 13.34 & $4.76^{\mathrm{d}}$ & 1.18 & $*$ \\
\hline
\end{tabular}

a-d Means, within a row, that don't share common superscript differ significantly ( $\mathrm{p} \leq 0.05)$.

1- $\mathrm{CAL}=$ control feed continuously provided ad libitum

2- Feed provided ad libitum except for 24-hrs removal period at 12 and 18 days of age.

3- Feed provided ad libitum except for 24-hrs removal period at 12, 18, 24 and 30 days of age.

4- Feed provided ad libitum except for 24-hrs removal period at 12, 18, 24, 30, 36 and 42 days of age.

5- $\mathrm{SEM}=$ stander error of mean

6- NS=Not significant

7- Metabolic= values represent the combined occurrence of sudden death syndrome, ascites and skeletal abnormalities

8- Nonmetabolic $=$ values represent mortality due to undetermined or factors other than those listed above. 
Table 3. Carcass characteristics of Japanese quail subjected to ad libitum or various SKD feeding regimes

\begin{tabular}{|c|c|c|c|c|c|c|}
\hline \multirow[b]{2}{*}{ Items } & \multicolumn{6}{|c|}{ SKD feeding regimes } \\
\hline & $\mathrm{CAL}^{1}$ & $\mathrm{SKD}_{2}^{2}$ & $\mathrm{SKD}_{4}{ }^{3}$ & SKD $_{6}^{4}$ & $\begin{array}{l}\text { Pooled } \\
\text { SEM }^{5} \pm\end{array}$ & Significance \\
\hline Live body weight & 197.18 & 197.28 & 198.0 & 196.73 & 1.55 & $\mathrm{NS}^{6}$ \\
\hline Liver weight $\%$ & $1.86^{\mathrm{d}}$ & $2.04^{\mathrm{c}}$ & $2.18^{\mathrm{b}}$ & $3.31^{\mathrm{a}}$ & 0.09 & $*$ \\
\hline Heart weight $\%$ & $0.94^{\mathrm{c}}$ & $1.02^{\mathrm{b}}$ & $1.06^{\mathrm{a}}$ & $1.09^{\mathrm{a}}$ & 0.01 & $*$ \\
\hline Gizzard weight $\%$ & $2.21^{\mathrm{d}}$ & $2.31^{\mathrm{c}}$ & $2.41^{\mathrm{b}}$ & $2.51^{\mathrm{a}}$ & 0.02 & $*$ \\
\hline Edible parts weight $\%$ & $5.01^{\mathrm{c}}$ & $5.37^{\mathrm{bc}}$ & $5.65^{\mathrm{b}}$ & $6.91^{\mathrm{a}}$ & 0.11 & $*$ \\
\hline Dressing weight $\%$ & 62.28 & 62.18 & 62.18 & 62.12 & 0.58 & NS \\
\hline Total edible parts weight $\%$ & $67.29^{\mathrm{b}}$ & $67.55^{\mathrm{b}}$ & $67.83^{\mathrm{b}}$ & $69.03^{\mathrm{a}}$ & 0.98 & $*$ \\
\hline Total inedible parts weight $\%$ & $32.71^{\mathrm{a}}$ & $32.45^{\mathrm{ab}}$ & $32.17^{\mathrm{b}}$ & $30.97^{\mathrm{b}}$ & 0.35 & $*$ \\
\hline Abdominal fat $\%$ & $1.44^{\mathrm{a}}$ & $1.15^{\mathrm{b}}$ & $0.92^{\mathrm{c}}$ & $0.55^{\mathrm{d}}$ & 0.09 & $*$ \\
\hline Small intestine length, cm & $75.50^{\mathrm{c}}$ & $82.0^{\mathrm{c}}$ & $92.50^{\mathrm{b}}$ & $114.33^{\mathrm{a}}$ & 1.16 & $*$ \\
\hline Cecum length, $\mathrm{cm}$ & $7.50^{\mathrm{c}}$ & $7.88^{\mathrm{c}}$ & $8.33^{\mathrm{b}}$ & $10.20^{\mathrm{a}}$ & 0.23 & $*$ \\
\hline $\begin{array}{l}\text { a-d Means, within a row, that don } \\
\text { 1- CAL= control feed continuous } \\
\text { 2- Feed provided ad libitum excep } \\
\text { 3- Feed provided ad libitum excep } \\
\text { 4- Feed provided ad libitum excep } \\
\text { 5- SEM=stander error of mean } \\
\text { 6- NS=Not significant }\end{array}$ & $\begin{array}{l}\text { re commo } \\
\text { vided ad } 1 \\
24-\mathrm{hrs} \text { rer } \\
24 \text {-hrs rer } \\
24 \text {-hrs rer }\end{array}$ & $\begin{array}{l}\text { uperscript } \\
\text { um } \\
\text { al period a } \\
\text { al period a } \\
\text { al period a }\end{array}$ & $\begin{array}{l}\text { fer signifi } \\
2 \text { and } 18 \\
2,18,24 \\
2,18,24\end{array}$ & $\begin{array}{l}\text { ly }(\mathrm{p} \leq 0.05 \\
\text { of age. } \\
30 \text { days of } \\
36 \text { and } 42\end{array}$ & age. & \\
\hline
\end{tabular}

Table 4. Carcass and liver chemical composition of Japanese quail subjected to ad libitum or various SKD feeding regimes

\begin{tabular}{|c|c|c|c|c|c|c|}
\hline \multirow[b]{2}{*}{ Items } & \multicolumn{6}{|c|}{ SKD feeding regimes } \\
\hline & $\mathrm{CAL}^{1}$ & $\mathrm{SKD}_{2}{ }^{2}$ & $\mathrm{SKD}_{4}{ }^{3}$ & SKD $_{6}{ }^{4}$ & Pooled SEM $^{5} \pm$ & Significance \\
\hline \multicolumn{7}{|l|}{ In carcass } \\
\hline Moisture \% & $69.29^{\mathrm{a}}$ & $68.98^{\mathrm{a}}$ & $67.87^{\mathrm{b}}$ & $65.89^{c}$ & 0.44 & $*$ \\
\hline Dry matter \% & $31.71^{\mathrm{b}}$ & $31.98^{\mathrm{b}}$ & $31.13^{\mathrm{b}}$ & $34.11^{\mathrm{a}}$ & 0.43 & $*$ \\
\hline Crude protein $\%$ & $61.56^{\mathrm{b}}$ & $62.73^{\mathrm{b}}$ & $63.69^{\mathrm{b}}$ & $66.58^{\mathrm{a}}$ & 0.54 & $*$ \\
\hline Ether extract \% & $33.58^{\mathrm{a}}$ & $32.19^{\mathrm{ab}}$ & $31.21^{\mathrm{b}}$ & $27.15^{\mathrm{c}}$ & 0.60 & * \\
\hline Ash $\%$ & $4.01^{\mathrm{c}}$ & $4.48^{\mathrm{b}}$ & $4.50^{\mathrm{b}}$ & $5.67^{\mathrm{a}}$ & 0.16 & $*$ \\
\hline Nitrogen free extract $\%$ & $0.75^{\mathrm{a}}$ & $0.60^{\mathrm{b}}$ & $0.60^{\mathrm{b}}$ & $0.60^{\mathrm{b}}$ & 0.02 & $*$ \\
\hline \multicolumn{7}{|l|}{ In liver } \\
\hline 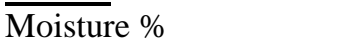 & 78.38 & 78.11 & 78.0 & 78.36 & 0.55 & $N S^{6}$ \\
\hline Dry matter $\%$ & 21.62 & 21.89 & 22.0 & 21.64 & 0.22 & NS \\
\hline Crude protein $\%$ & $60.53^{\mathrm{d}}$ & $61.11^{\mathrm{c}}$ & $64.58^{\mathrm{b}}$ & $65.18^{\mathrm{a}}$ & 0.36 & $*$ \\
\hline Ether extract \% & $29.16^{\mathrm{c}}$ & $30.96^{\mathrm{b}}$ & $33.46^{\mathrm{a}}$ & $34.16^{\mathrm{a}}$ & 0.41 & $*$ \\
\hline Ash \% & 5.31 & 5.16 & 5.20 & 5.74 & 0.12 & NS \\
\hline $\begin{array}{l}\text { a-d Means, within a row, that } \\
\text { 1- CAL= control feed continu } \\
\text { 2- Feed provided ad libitum ex } \\
\text { 3- Feed provided ad libitum ex } \\
\text { 4- Feed provided ad libitum ex } \\
\text { 5- SEM=stander error of mean } \\
\text { 6- NS=Not significant }\end{array}$ & $\begin{array}{l}\text { t share co } \\
\text { y provided } \\
\text { t for } 24-\mathrm{hr} \\
\mathrm{t} \text { for } 24-\mathrm{hr} \\
\mathrm{t} \text { for } 24-\mathrm{hr}\end{array}$ & $\begin{array}{l}\text { mon supersc } \\
\text { d libitum } \\
\text { removal per } \\
\text { removal per } \\
\text { removal per }\end{array}$ & $\begin{array}{l}\text { pt differ si } \\
\text { d at } 12 \text { and } \\
\text { d at } 12,18 \\
\text { d at } 12,18\end{array}$ & $\begin{array}{l}\text { ificantly (p } \\
8 \text { days of a } \\
4 \text { and } 30 \mathrm{~d} \\
4,30,36 \text { a }\end{array}$ & $\begin{array}{l}0.05) \text {. } \\
\text { e. } \\
\text { ys of age. } \\
\text { d } 42 \text { days of age. }\end{array}$ & \\
\hline
\end{tabular}


Table 5. Tibia measurements for Japanese quail subjected to ad libitum or various SKD feeding regimes

\begin{tabular}{|c|c|c|c|c|c|c|}
\hline \multirow[b]{2}{*}{ Items } & \multicolumn{5}{|c|}{ SKD feeding regimes } & \multirow[b]{2}{*}{ Significance } \\
\hline & CAL $^{1}$ & SKD $_{2}{ }^{2}$ & $\mathrm{SKD}_{4}{ }^{3}$ & SKD $_{6}{ }^{4}$ & $\begin{array}{l}\text { Pooled } \\
\text { SEM }^{5} \pm\end{array}$ & \\
\hline Tibia weight, (g) & $7.72^{\mathrm{c}}$ & $8.06^{\mathrm{b}}$ & $8.53^{\mathrm{a}}$ & $8.90^{\mathrm{a}}$ & 0.14 & $*$ \\
\hline Tibia length,(cm) & $4.76^{\mathrm{c}}$ & $5.0^{\mathrm{b}}$ & $5.20^{\mathrm{a}}$ & $5.36^{\mathrm{a}}$ & 0.13 & $*$ \\
\hline Tibia width , (cm) & 0.20 & 0.22 & 0.26 & 0.26 & 0.01 & $\mathrm{NS}^{6}$ \\
\hline Tibia ash, $(\%)$ & $28.60^{\mathrm{d}}$ & $30.0^{\mathrm{c}}$ & $31.22^{\mathrm{b}}$ & $33.26^{\mathrm{a}}$ & 0.45 & $*$ \\
\hline Tibia calcium, (\% of ash) & $8.16^{\mathrm{d}}$ & $9.50^{\mathrm{c}}$ & $9.59^{\mathrm{b}}$ & $10.88^{\mathrm{a}}$ & 0.22 & $*$ \\
\hline Tibia phosphorous, (\% of ash) & 4.12 & 4.09 & 4.16 & 4.15 & 0.08 & NS \\
\hline Tibia dyschondroplasia, $(\%)$ & $16.57^{\mathrm{a}}$ & $13.04^{\mathrm{b}}$ & $11.83^{\mathrm{c}}$ & $9.39^{\mathrm{d}}$ & 0.57 & $*$ \\
\hline $\begin{array}{l}\text { a-d Means, within a row, that don } \\
\text { 1- CAL= control feed continuously } \\
\text { 2- Feed provided ad libitum except } \\
\text { 3- Feed provided ad libitum except } \\
\text { 4- Feed provided ad libitum except } \\
\text { 5- SEM=stander error of mean } \\
\text { 6- NS=Not significant }\end{array}$ & $\begin{array}{l}\text { hare com } \\
\text { ovided ad } \\
24 \text {-hrs re } \\
24 \text {-hrs re } \\
24 \text {-hrs re }\end{array}$ & $\begin{array}{l}\text { superscri } \\
\text { tum } \\
\text { yal period } \\
\text { al period } \\
\text { al period }\end{array}$ & $\begin{array}{l}\text { iffer signif } \\
2 \text { and } 18 d \\
2,18,24 \\
2,18,24\end{array}$ & $\begin{array}{l}\text { tly ( } \mathrm{p} \leq 0.0 \\
\text { of age. } \\
0 \text { days of } \\
6 \text { and } 42\end{array}$ & $\begin{array}{l}\text { ys of age. } \\
\text { ys }\end{array}$ & \\
\hline
\end{tabular}

Table 6. Hematological parameters and some blood constituents of Japanese quail subjected to ad libitum or various SKD feeding regimes

\begin{tabular}{|c|c|c|c|c|c|c|}
\hline \multirow[b]{2}{*}{ Items } & \multicolumn{5}{|c|}{ SKD feeding regimes } & \multirow[b]{2}{*}{ Significance } \\
\hline & CAL $^{1}$ & $\mathrm{SKD}_{2}{ }^{2}$ & $\mathrm{SKD}_{4}{ }^{3}$ & SKD $_{6}{ }^{4}$ & $\begin{array}{l}\text { Pooled } \\
\text { SEM }^{5}\end{array}$ & \\
\hline \multicolumn{7}{|l|}{ Hematological parameters: } \\
\hline Total WBCs $\left(\right.$ cells $\left./ \mathrm{mm}^{3}\right)$ & $12.510^{\mathrm{b}}$ & $14.115^{\mathrm{a}}$ & $14.360^{\mathrm{a}}$ & $14.160^{\mathrm{a}}$ & 0.16 & $*$ \\
\hline Total RBCs (cells $\left.\times 10^{3} / \mathrm{mm}^{3}\right)$ & $2.561^{\mathrm{b}}$ & $3.220^{\mathrm{a}}$ & $3.222^{\mathrm{a}}$ & $3.321^{\mathrm{a}}$ & 0.12 & $*$ \\
\hline \multicolumn{7}{|l|}{ Differential cell count $(\%) *$} \\
\hline Hetrophils $(\%)$ & $17.94^{\mathrm{c}}$ & $23.36^{\mathrm{b}}$ & $28.90^{\mathrm{a}}$ & $29.61^{\mathrm{a}}$ & 1.04 & * \\
\hline Lymphcytes (\%) & $40.60^{\mathrm{c}}$ & $43.15^{\mathrm{b}}$ & $45.22^{\mathrm{ab}}$ & $46.15^{\mathrm{a}}$ & 0.59 & $*$ \\
\hline $\mathrm{H} / \mathrm{L}$ ratio & $0.44^{\mathrm{c}}$ & $0.54^{\mathrm{b}}$ & $0.64^{\mathrm{a}}$ & $0.64^{\mathrm{a}}$ & 0.02 & $*$ \\
\hline $\mathrm{PCV} \%$ & $35^{\mathrm{b}}$ & $36^{\mathrm{b}}$ & $36^{\mathrm{b}}$ & $38^{\mathrm{a}}$ & 0.55 & $*$ \\
\hline $\mathrm{Hb}(\mathrm{g} / 100 \mathrm{~mL})^{7}$ & $11.66^{\mathrm{c}}$ & $12^{\mathrm{b}}$ & $12^{\mathrm{b}}$ & $12.66^{\mathrm{a}}$ & 0.16 & $*$ \\
\hline $\operatorname{MCV}(\mu)^{8}$ & 77 & 78 & 78 & 77 & 0.22 & $\mathrm{NS}^{6}$ \\
\hline $\mathrm{MCH}(\mathrm{pg} / \mathrm{cell})^{9}$ & 26 & 26 & 26 & 26 & 0.17 & NS \\
\hline $\operatorname{MCHC}(\%)^{10}$ & 33 & 33 & 33 & 33 & 0.26 & NS \\
\hline \multicolumn{7}{|l|}{ Biochemical blood analysis: } \\
\hline Total lipids $(\mathrm{mg} / 100 \mathrm{~mL})$ & $541.22^{\mathrm{c}}$ & $567.08^{\mathrm{bc}}$ & $595.84^{\mathrm{b}}$ & $652.98^{\mathrm{a}}$ & 9.96 & * \\
\hline Total triglycerides $(\mathrm{mg} / 100 \mathrm{~mL})$ & $170.18^{\mathrm{c}}$ & $182.64^{\mathrm{b}}$ & $181.87^{\mathrm{b}}$ & $180.84^{\mathrm{a}}$ & 1.58 & $*$ \\
\hline Total cholesterol (mg/100mL) & $160.49^{b}$ & $170.97^{\mathrm{a}}$ & $171.83^{\mathrm{a}}$ & $174.79^{\mathrm{a}}$ & 1.44 & $*$ \\
\hline Total glucose (mg/100mL) & 209.13 & 208.96 & 209.01 & 209.18 & 0.76 & NS \\
\hline \multicolumn{7}{|l|}{ Hormone assays concentrations: } \\
\hline $\mathrm{T} 3$ (ng/100mL) & $2.20^{\mathrm{a}}$ & $2.05^{\mathrm{ab}}$ & $1.91 b^{c}$ & $1.84^{\mathrm{c}}$ & 1.04 & $*$ \\
\hline $\mathrm{T} 4(\mu \mathrm{g} / 100 \mathrm{~mL})$ & $3.86^{\mathrm{a}}$ & $2.76^{\mathrm{b}}$ & $2.72^{\mathrm{b}}$ & $2.06^{\mathrm{c}}$ & 0.62 & $*$ \\
\hline Corticosterone (ng/100mL) & $6.41^{\mathrm{c}}$ & $8.62^{\mathrm{b}}$ & $8.99^{\mathrm{b}}$ & $10.89^{\mathrm{a}}$ & 0.37 & $*$ \\
\hline $\begin{array}{l}\text { a-d Means, within a row, that don`t } \\
\text { 1- CAL= control feed continuously } \mathrm{p} \\
\text { 2- Feed provided ad libitum except } \mathrm{f} \\
\text { 3- Feed provided ad libitum except } \mathrm{f} \\
\text { 4- Feed provided ad libitum except } \mathrm{f} \\
\text { 5- SEM=stander error of mean } \\
\text { 6- NS=Not significant } \\
\text { *- Differential count of } 100 \text { leukocyt } \\
\text { 7- Hb= PCV/3 } \\
\text { 8- MCV }=\% \text { Htx10/RBCs } \\
\text { 9- MCH= Hbx10/RBCss } \\
\text { 10- } \mathrm{MCHC}=\mathrm{Hb} \times 100 / \% \mathrm{Ht}\end{array}$ & $\begin{array}{l}\text { hon supersc } \\
\text { libitum } \\
\text { emoval peri } \\
\text { emoval peri } \\
\text { emoval peri } \\
\text { d smear. }\end{array}$ & $\begin{array}{l}\text { ipt differ si } \\
\text { d at } 12 \text { and } \\
\text { d at } 12,18 \\
\text { d at } 12,18\end{array}$ & $\begin{array}{l}\text { nificantly ( } \\
8 \text { days of a } \\
24 \text { and } 30 \\
24,30,36\end{array}$ & $\begin{array}{l}\leq 0.05) \text {. } \\
\text { e. } \\
\text { hys of age. } \\
\text { hd } 42 \text { days }\end{array}$ & age. & \\
\hline
\end{tabular}


Table 7. Feed costs for 43-day old Japanese quail subjected to ad libitum or various SKD feeding regimes

\begin{tabular}{|c|c|c|c|c|c|}
\hline \multirow{2}{*}{ Items } & & \multicolumn{4}{|c|}{ SKD feeding regimes } \\
\hline & & $\mathrm{CAL}^{1}$ & SKD $_{2}{ }^{2}$ & $\mathrm{SKD}_{4}{ }^{3}$ & SKD $_{6}{ }^{4}$ \\
\hline \multicolumn{6}{|c|}{ Total amount of feed consumed during the experimental period } \\
\hline (kg/bird) & A & 0.593 & 0.571 & 0.528 & 0.493 \\
\hline Price of one $\mathrm{kg}$ feed $(\mathrm{LE})^{5} \quad \mathrm{~B}$ & & 2.16 & 2.16 & 2.16 & 2.16 \\
\hline \multicolumn{6}{|l|}{ Cost of feed consume during the experimental period (LE) } \\
\hline$(\mathrm{Ax} \mathrm{B})$ & $\mathrm{C}$ & 1.28 & 1.23 & 1.14 & 1.07 \\
\hline Selling price of one chick at 7 day of age (LE) ${ }^{6}$ & $\mathrm{D}$ & 1.75 & 1.75 & 1.75 & 1.75 \\
\hline Cost of husbandry for one bird (LE) ${ }^{7}$ & $\mathrm{E}$ & 0.85 & 0.85 & 0.85 & 0.85 \\
\hline Total cost (LE) & $\mathrm{F}$ & 3.88 & 3.83 & 3.74 & 3.67 \\
\hline Final LBW (kg/bird) & $\mathrm{G}$ & 0.19906 & 0.19920 & 0.19842 & 0.19848 \\
\hline Selling price of one quail at 43 day of age (LE) & $\mathrm{H}$ & 7.0 & 7.0 & 7.0 & 7.0 \\
\hline Net revenue $(\mathrm{H}-\mathrm{F})$ & I & 3.12 & 3.17 & 3.26 & 3.33 \\
\hline Economical efficiency ${ }^{8}$ & $\mathbf{J}$ & 0.80 & 0.83 & 0.87 & 0.91 \\
\hline \multicolumn{2}{|c|}{ Relative economical efficiency $\mathrm{J} / \mathrm{J}$ of the control CAL x100 ${ }^{9}$} & 100 & 103.75 & 108.75 & 113.75 \\
\hline
\end{tabular}

1- CAL = control feed continuously provided ad libitum

2- Feed provided ad libitum except for 24-hrs removal period at 12 and 18 days of age.

3- Feed provided ad libitum except for 24-hrs removal period at 12, 18, 24 and 30 days of age.

4- Feed provided ad libitum except for 24-hrs removal period at 12 18, 24, 30, 36 and 42 days of age.

5- Egyptian pound.

6- According to the local market price at the experimental time.

7- Cost of husbandry comprises price of drugs, light, heating, labor...etc.

8- Economical efficiency= (net return / total feed cost).

9- Relative economical efficiency= assuming economical efficiency of the control equals $100 \%$. 


\section{تأثير نظم التصويم على الأداء الإنتاجى وبعض مكونات الدم فى السمان اليابانى}

\section{عبدالعظيم فهمى عبدالعظيم}

كلية الزراعه، جامعه الأزهر، مدبنه نصر، القاهره، مصر

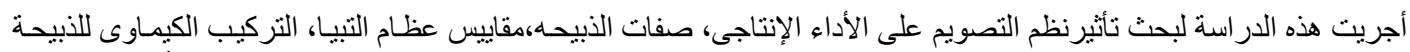

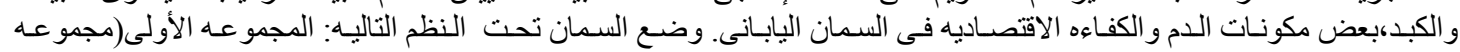

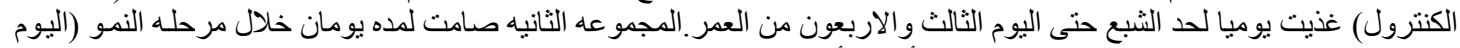

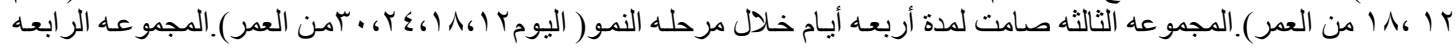

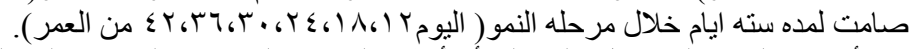

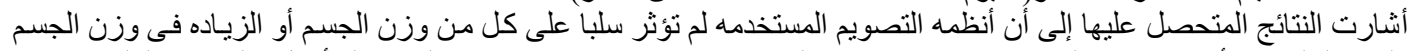

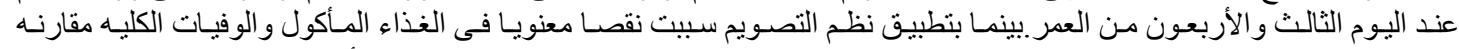

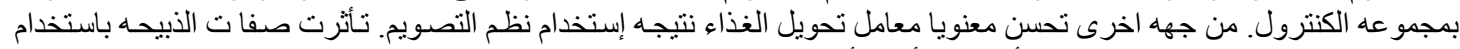

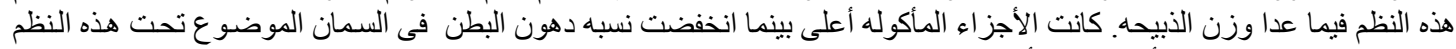

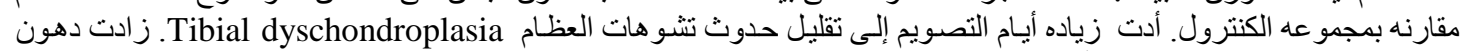

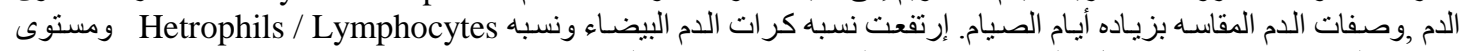

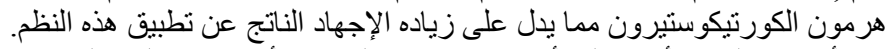

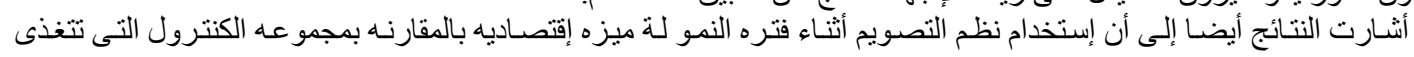

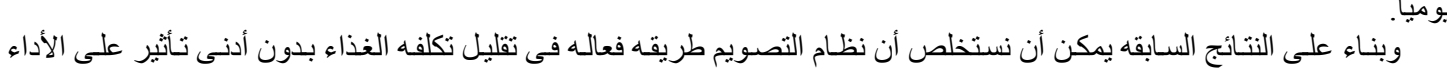

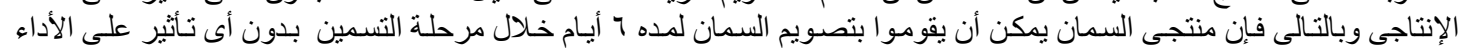

